\title{
Size Effect, Seasonality, Attitude to Risk and Performance of Egyptian Banks
}

\author{
Nader Alber ${ }^{1}$ \\ ${ }^{1}$ Faculty of Commerce-Ain Shams University, Egypt \\ Correspondence: Nader Alber, Faculty of Commerce-Ain Shams University, Cairo, Egypt. Tel: \\ 002-010-0566-8507. E-mail: naderalberfanous@yahoo.com
}

Received: October 17, 2013

Accepted: October 23, 2013

Online Published: December 23, 2013

doi: 10.5539/ibr.v7n1p82

URL: http://dx.doi.org/10.5539/ibr.v7n1p82

\begin{abstract}
This paper aims at analyzing the effects of "size", "seasonality" and "attitude to risk" on the performance Egyptian banks. This has been conducted using a sample of 10 banks, and covering the period from the first quarter2003 to the fourth quarter 2011.

Results indicate that, hypotheses regarding the significance of differences between performance indicators, according to "size", "seasonality" and "attitude to risk" on the performance Egyptian banks could be accepted.

Also, robustness check assures the significance of these effects, where indicators of both capital adequacy and earnings are affected by both of size and attitude to risk, while asset quality is affected by size and seasonality.
\end{abstract}

Keywords: attitude to risk, CAMEL, Egyptian banks, size effect, seasonality

\section{Introduction}

Egyptian banks have expanded their activities that the growing assets, deposits, and loans reflect, during the period from 2005 to 2011. This period witnessed growing in banking activities that table (1) illustrates (in LE $\mathrm{mn})$.

Table 1. Development of Egyptian banking activities from 2005 to 2011

\begin{tabular}{ccccc}
\hline At end of June & Assets & Deposits & Loans & Equity \\
\hline 2005 & 705146 & 519649 & 308195 & 35368 \\
2006 & 761562 & 568841 & 324041 & 40530 \\
2007 & 937923 & 649953 & 353746 & 45589 \\
2008 & 1083311 & 747199 & 401425 & 53436 \\
2009 & 1091993 & 809694 & 429957 & 62921 \\
2010 & 1220655 & 892492 & 465990 & 75084 \\
$\mathbf{2 0 1 1}$ & 1269690 & 957037 & 474139 & 81105 \\
\hline
\end{tabular}

Source: Central Bank of Egypt (2011) Annual Report.

Changes in performance indicators encourage illustrating their determinants and the orientation of this paper is based on using "bank size", "seasonality" and "attitude to risk" as determinants of "banking performance" and on using CAMEL as an approach of "performance evaluation". Table 2 illustrates the development of Egyptian banks' performance from 2008 till 2011, as follows: 
Table 2. Development of Egyptian banking performance from 2008 to 2011

\begin{tabular}{|c|c|c|c|c|c|}
\hline Item & Indicator & 2008 & 2009 & 2010 & 2011 \\
\hline \multirow[t]{3}{*}{ Capital Adequacy } & Capital Base to Risk weighted assets & 0.147 & 0.151 & 0.163 & 0.156 \\
\hline & Tier 1 Capital to Risk-Weighted Assets & 0.115 & 0.120 & 0.127 & 0.130 \\
\hline & Net Worth to Assets & 0.062 & 0.064 & 0.067 & 0.062 \\
\hline \multirow[t]{3}{*}{ Asset Quality } & Nonperforming Loans to Total Loans & 0.148 & 0.134 & 0.136 & 0.109 \\
\hline & Loan Provisions to Nonperforming Loans & 0.921 & 1.004 & 0.925 & 0.946 \\
\hline & Loans to Private Sector to Loans to Customers & 0.839 & 0.810 & 0.805 & 0.811 \\
\hline \multirow[t]{3}{*}{ Earnings } & Return on Average Assets & 0.008 & 0.008 & 0.010 & 0.010 \\
\hline & Return on Average Equity & 0.141 & 0.130 & 0.143 & 0.143 \\
\hline & Net Interest Margin & 0.017 & 0.022 & 0.023 & 0.023 \\
\hline \multirow[t]{5}{*}{ Liquidity } & Liquidity Ratio: Local Currency & 0.345 & 0.434 & 0.447 & 0.554 \\
\hline & Liquidity Ratio: Foreign Currencies & 0.468 & 0.410 & 0.406 & 0.511 \\
\hline & Securities to Assets & 0.122 & 0.138 & 0.180 & 0.182 \\
\hline & Deposits to Assets & 0.784 & 0.824 & 0.810 & 0.754 \\
\hline & Loans to Deposits & 0.577 & 0.577 & 0.518 & 0.500 \\
\hline
\end{tabular}

Source: Central Bank of Egypt (2011) Economic Review.

Early attempts to measure banks' performance using CAMEL components and financial ratios abound in the literature from Beaver (1966) and Altman (1968) to Maishanu (2004), Wirnkar and Tanko (2008), Tatom and Houston (2011).

Beaver (1966) is the first attempt using financial ratios for predicting bankruptcy, while Altman (1968) uses a multiple discriminate analysis (MDA) and combines the information from several financial ratios in a single prediction model (Altman's Z-score model). In addition, Maishanu (2004) identifies 8 financial ratios that could serve in informing the financial state of a bank and predicting failure in commercial banks.

Wirnkar and Tanko (2008) brings forth a new acronym for CAMEL known as CLEAM in order to reflect the magnitude and ability of each component to capture the performance of a bank in descending order. Tatom and Houston (2011) proposes some regulatory standards embodied CAMEL rating system, as well as several economic variables (like real price of energy, currency ratio and the interest rate spread) to produce a robust model that forecasts bank failure for the entire commercial bank industry in the United States.

CAMEL(S) theory may be viewed as a progressive update of the theory of bank liquidity market failure that includes the major risks in the entire bank balance sheet (King et al., 2006). The CAMEL framework essentially provides bank regulators with off-site surveillance basis for bank rating (Gilbert et al., 2002). Njoku (2012) shows how bank auditors can apply to combination of CAMEL and non-CAMEL factors model to strengthen the audit risk model.

Cole and Gunther $(1995$, p. 4) show that based on the results of these on-site evaluations, regulators then rate the performance of individual banks along five key dimensions: capital adequacy, asset quality, management, earnings, and liquidity. Each of the five areas of performance are rated on a scale of 1 to 5 as follows: 1 strong performance, 2 satisfactory performance, 3 performance that is flawed to some degree, 4 marginal performance that is significantly below average, and 5 unsatisfactory performance that is critically deficient and in need of immediate remedial action. Once each of the five areas of performance has been assigned a rating, a composite, or overall, rating is derived, again on a scale from 1 to 5 .

The US formulation adds the variable (S) in 1997 to represent sensitivity to market risk (Gunter \& Moore, 2003). The introduction of Troubled Asset Relief Program (TARP) in 2008 constitutes significant regulatory regime changes, and provides the necessary framework to explore whether regime-dependent risk-shifting or risk-taking is present.

In brief, this study tries to answer these three main questions: 
- Does "bank size" affect its performance, as measured by CAMEL approach? By other words: Are there any significant differences in "banking performance", due to the bank size?

- Does "seasonality" affect "banking performance"? By other words: Are there any significant differences in "banking performance", due to the quarter of evaluation?

- Does "attitude towards risk" affect "banking performance"? By other words: Are there any significant differences in "banking performance", due to their degree of "conservatism" or "aggressiveness"?

This paper addresses a main question about determinants of "banking performance", as measured by CAMEL. Determinants of performance, to be examined, are variables related to "bank size", "seasonality" and "attitude towards risk".

The paper is arranged as follows: after this introduction, section 2 reviews research literature that has concerned with "banking performance", as measured by CAMEL indicators and "banking characteristics" that include size, seasonality and attitude to risk. Section 3 explains how to measure research variables and illustrates how to test the hypotheses. Section 4 is for empirical work, presenting results, discussing how these results answer research questions using ANOVA and providing a robustness check using step-wise regression technique. Section 5 summarizes the paper and provides remarks about conclusions.

\section{Literature Review}

This section tries to present some of previous work, which has been conducted in the field of "banking performance", as measured by CAMEL indicators and banking characteristics that include size, seasonality and attitude to risk.

Regarding "banking performance", many studies evaluate it according to CAMEL approach. Concerning with capital adequacy (C), Berger et al. (2008) demonstrates the reasons for this "excess" capital using annual panel data from 1992 through 2006. Results indicate that U.S. banks hold significantly more equity capital than required by their regulators. Besides, findings show that BHCs actively manage their capital ratios (as opposed to passively allowing capital to build up via retained earnings), set target capital levels substantially above well-capitalized regulatory minima, and (especially poorly capitalized BHCs) make rapid adjustments toward their targets.

Barth et al. (2008) presents survey information on bank regulations in 142 countries. Following Basel guidelines many countries strengthened capital regulations and official supervisory agencies, but results show that these reforms don't enhance stability or efficiency. While some countries have empowered private monitoring of banks, consistent with the third pillar of Basel II, there are many exceptions and reversals along this dimension.

Guidara et al. (2010) documents the countercyclical behavior of Canadian banks' capital buffer from 1982 to 2010 for the six largest Canadian chartered banks. Results show that the adoption of Canadian banking regulations is effective in rendering Canadian banks' capital countercyclical to business cycles. Findings indicate that Canadian banks hold more capital buffer in recession than in expansion.

Demirgüç-Kunt and Detragiache (2011) studies the effect of compliance with the Basel core principles for effective banking supervision on bank soundness. Using data for more than 3000 banks in 86 countries, the authors find that neither the overall index of compliance with the Basel core principles nor the individual components of the index are robustly associated with bank risk measured by Z-scores. This may cast doubt on the usefulness of the Basel core principles in ensuring bank soundness.

Al-Farisi and Hendrawan (2012) examines the impact of capital structure on performance of conventional and Islamic banks, by using profit efficiency approach. They measure profit efficiency score for each bank in Indonesia during the period from 2002 to 2008 by using distribution free approach (DFA). Result indicate that banks' capital ratio have a negative effect on their profit efficiency.

Osborne et al. (2012) assesses the relation between bank capital ratios and lending rates for the 8 largest UK banks over the period from 1998 to 2011. Results show a strong negative association during the stressed conditions of the period from 2007 to 2011 when well-capitalized banks may have benefited from lower funding costs.

Concerning with Asset Quality (A), Hassan and Sanchez (2007) examines banking performance concerning with asset quality (beside capital adequacy and earnings), using Data Envelopment Analysis (DEA). The authors estimate and compare the efficiency and productivity of seven Latin American countries (Argentina, Brazil, Chile, Colombia, Ecuador, Mexico and Venezuela) during the period from 1996 to 2003. The study finds that most of the sources of inefficiencies are regulatory rather than technical. This means that bank managers do not 
choose the correct (optimal) input and output mix, because they are not forced to do so by the environmental conditions (either government regulations or market conditions).

Another important study of Acharya et al. (2009) shows that market freezes depend on how information about asset quality is revealed. They illustrate that when there is a constant probability that "bad news" is revealed each period and, in the absence of bad news, the value of the assets is high. By contrast, for the "good news", the value of the assets is low.

Concerning with Earnings (E), Curry et al. (2006) quantifies the impact of bank supervision (measured using CAMEL composite and component ratings) on loan growth. The authors perform dynamic loan growth equations using regressions for two distinct sub-periods: (1) 1985 to 1993 (covers the credit crunch period), and (2) 1994 to 2004 (covers the sustained recovery period). For the first period, they find that business lending is the most sensitive to changes in CAMEL ratings, while for the second period; they find little evidence that changes in CAMEL ratings had any systematic effect on loan growth.

Paul and Kaestner (2007) analyzes the banking industry's profitability, using a sample of around 3000 European banks. Results show that the institutional characteristic ownership of savings banks is the most powerful input factor. Banks located in countries with a minimum initial privatization success indicate a significantly higher profitability than banks resident in countries with publicly dominated savings banks sectors.

Gayed et al. (2009) addresses the effects of marketing mix on performance indicators, using a sample of 14 banks (out of 33 banks in Egypt) at the end of June 2008. Results indicate the effects of "number of services" and "number of tellers" on bank profitability.

Ben Naceur and Omran (2011) examines the impact of bank regulation, concentration, and development on bank profitability across a broad selection of Middle East and North Africa (MENA) countries, during the period from 1989 to 2005 . The empirical results suggest that bank-specific characteristics, in particular bank capitalization and credit risk, have a positive and significant impact on banks' net interest margin and cost efficiency.

Petrella and Resti (2012) investigates the information role of the stress tests. They examine the 2011 European stress test exercise to assess whether and how it affected bank stock prices (and consequently bank profitability). Using event study analysis of 3400 data points for 90 banks, results show that informational content is considered relevant by investors.

Concerning with Liquidity (L), Banking liquidity risks are due to two reasons: the first is represented by liabilities side, where depositors withdraw of their deposits, and this requires sufficient liquidity to meet these requirements. The second is due to assets side, where the bank should have sufficient liquidity to give required facilities to their borrowers (Saunders, 1994, p. 293).

Motivated by the current financial crisis, several papers seek to explain market freezes. Diamond and Rajan (2009) indicates that when banks have a significant quantity of assets with a limited set of potential buyers, shocks in future liquidity demands may trigger sales at fire sale prices.

Vazquez and Federico (2012) analyzes the performance of about 11000 banks in the U.S. and Europe during the period from 2001 to 2009. The results show that banks with weaker structural liquidity and higher leverage in the pre-crisis period were more likely to fail afterward. The likelihood of bank failure also increases with bank risk-taking.

Concerning with Size Effect (S), Carvallo and Kasman (2005) investigates the cost efficiency of a sample of 481 Latin American and Caribbean banks in 105 countries over the years from 1995 to 1999 using a stochastic frontier model (SFA). They use three inputs: loans, deposits, and other earning assets and three prices of factors of production: the price of labor, the price of purchased funds, and the price of physical capital. Results indicate that on average, very small and very large banks are significantly more inefficient than large banks.

Schaeck and Čihák (2007) uses data for more than 2600 European banks in 10 countries to test the effect of competition on capital ratios. Using panel data techniques, and distinguishing between the competitive conduct of small and large banks, they show that banks tend to hold higher capital ratios when operating in a more competitive environment.

Sahut and Mili (2009) studies bank distress in MENA countries and addresses the question of whether mergers are commonly considered as a solution for resolving individual bank distress. They challenge the view that specific bank indicators such as CAMEL category and bank size are significant determinants of bank distress. They investigate the distress and subsequent merger decisions for 330 banks from the MENA region during the period 2000-2007. Empirical evidence indicates that monetary policy indicators do not really affect bank distress 
and shows that distressed state-owned banks and large-sized banks are less likely to be a target in a merger transaction.

Berger and Bouwman (2011) discusses the effect of capital on bank performance. They have two main results. First, capital helps small banks to increase their probability of survival and market share at all times (during banking crises, market crises, and normal times). Second, capital enhances the performance of medium and large banks primarily during banking crises.

Anis and Sami (2012) investigates the cost efficiency of 17 Tunisian banks over the period 1997-2006 using a parametric approach stochastic (SFA), Findings suggest that private banks are more efficient than ownership banks; foreign banks are more efficient than domestic banks and small and medium-sized banks are more efficient than large ones.

Vazquez and Federico (2012) indicates that the smaller domestically-oriented banks were relatively more vulnerable to liquidity risk, while the large cross-border banks were more susceptible to solvency risk due to excessive leverage.

Concerning with Attitude to Risk (A), Berger et al. (2012) tests the effects of regulatory interventions and capital support on bank risk taking and liquidity creation over the period from 1999 to 2009 . Results indicate that there are no significant changes in risk taking and liquidity creation in the years preceding regulatory interventions and capital support. Evidence suggests that both types of actions may have important intended consequences (risk reduction) and potentially unintended consequences (diminished liquidity creation), with implications for policymakers.

Black and Hazelwood (2012) considers the effect of the TARP capital injections on bank risk taking by analyzing the risk ratings of banks' commercial loan originations during the crisis. The results indicate that, the risk of loan originations increased at large TARP banks but decreased at small TARP banks. For large banks, the increase in risk-taking without an increase in lending is suggestive of moral hazard due to government ownership.

Kanas (2013) addresses the relationship between bank dividends and bank risk over the period from 1984 to 2011. Results show strong evidence of risk-shifting and risk-taking over the post-PCA regime spanning the period from 1992 to 2008 . The finding of risk-taking suggests that risk-taking may be a factor contributing to this crisis

Regarding the current study, comparing with previous work, it's important to pinpoint some differences that may justify its importance, as follows:

1) The most of previous work focuses on only one of CAMEL dimensions, while the current study elaborates all of them.

2) Some papers concern with size effect and few of them investigate bank attitude to risk, while the current paper combines size effect, bank attitude to risk and seasonality, shedding a light on their effects on CAMEL indicators.

\section{Data Description and Hypotheses Developing}

Required data regarding bank size, seasonality, attitude to risk and CAMEL indicators could be shown as follows:

Table 3. Variables representing CAMEL indictors, size, seasonality and attitude to risk

\begin{tabular}{lll}
\hline Variable & Calculation & Sign \\
\hline Net Worth to Risky Assets & Net Worth / Risky Assets & $\mathrm{C} 1$ \\
Net Worth to Deposits & Net Worth / Deposits & $\mathrm{C} 2$ \\
Loan Provisions to Loans & Loan Provisions / Loans & $\mathrm{A} 1$ \\
Provisions to Assets & Provisions / Assets & $\mathrm{A} 2$ \\
Risky Assets to Assets & Risky Assets / Assets & $\mathrm{M}$ \\
Return on Equity & Net Profit / Equity & E1 \\
Return on Assets & Net Profit / Assets & E2 \\
\hline
\end{tabular}




$\begin{array}{lll}\text { Legal Reserve Ratio } & \text { Cash / Deposits } & \text { L1 } \\ \text { Legal Liquidity Ratio } & \text { Liquid Assets } / \text { Deposits } & \text { L2 } \\ \text { Bank Size }{ }^{(1)} & =1 \text { for small banks and }=1 \text { for big banks } & \text { SIZ } \\ \text { Seasonality (Q1) } & =1 \text { for the } 1^{\text {st }} \text { quarter and otherwise }=0 & \text { SEA1 } \\ \text { Seasonality (Q2) } & =1 \text { for the } 2^{\text {nd }} \text { quarter and otherwise }=0 & \text { SEA2 } \\ \text { Seasonality (Q3) } & =1 \text { for the } 1^{\text {st }} \text { quarter and otherwise }=0 & \text { SEA3 } \\ \text { Seasonality (Q4) } & =1 \text { for the } 4^{\text {th }} \text { quarter and otherwise }=0 & \text { SEA4 } \\ \text { Bank Attitude to Risk }{ }^{(2)} \text { (conservative) } & =1 \text { for conservative banks and otherwise }=0 & \text { ATR1 } \\ \text { Bank Attitude to Risk (m. conservative) } & =1 \text { for moderately conservative banks and otherwise }=0 & \text { ATR2 } \\ \text { Bank Attitude to Risk (aggressive) } & =1 \text { for moderate banks and otherwise }=0 & \text { ATR3 } \\ \text { Bank Attitude to Risk (m. aggressive) } & =1 \text { for moderately aggressive banks and otherwise }=0 & \text { ATR4 } \\ \text { Bank Attitude to Risk (aggressive) } & =1 \text { for aggressive banks and otherwise }=0 & \text { ATR5 }\end{array}$

This paper aims at testing the following three hypotheses:

1) There is no significant effect of "bank size" on its performance as measured by CAMEL approach.

2) There is no significant effect of "seasonality" on bank performance as measured by CAMEL approach.

3) There is no significant effect of "bank attitude to risk" on its performance as measured by CAMEL approach.

Regarding the first hypothesis, the null hypothesis H0states that, for each CAMEL indicator:

$$
\mu_{C A M E L=S M A L L}=\mu_{C A M E L-B I G}
$$

The alternative hypothesis $\mathrm{H}_{\mathrm{a}}$ could be shown as:

$$
\mu_{\text {CAMEL-SAMLL }} \neq \mu_{\text {camel-BIG }}
$$

Regarding the second hypothesis, the null hypothesis H0states that, for each CAMEL indicator:

$$
\mu_{C A M E L-Q 4}=\mu_{C A M E L-Q 2}=\mu_{C A M E L-Q 3}=\mu_{C A M E L-Q 4}
$$

The alternative hypothesis $\mathrm{H}_{\mathrm{a}}$ could be shown as:

$$
\mu_{C A M E L-Q 4} \neq \mu_{C A M E L-Q 2} \neq \mu_{C A M E L-Q 3} \neq \mu_{C A M E L-Q 4}
$$

Regarding the third hypothesis, the null hypothesis $\mathrm{H}_{0}$ states that, for each CAMEL indicator:

$$
\mu_{C A M E L-Q 4}=\mu_{C A M E L-Q 2}=\mu_{C A M E L-Q 3}=\mu_{C A M E L-Q 4}=\mu_{C A M E L-Q 5}
$$

The alternative hypothesis $\mathrm{H}_{\mathrm{a}}$ could be shown as:

$$
\mu_{C A M E L-Q 4} \neq \mu_{C A M E L-Q 2} \neq \mu_{C A M E L-Q 3} \neq \mu_{C A M E L-Q 4} \neq \mu_{C A M E L-Q 5}
$$

Robustness checks test the significance of differences between CAMEL indicators according banks size, seasonality and attitude to risk could be shown, for each CAMEL indicator ( $\mathrm{I}_{\mathrm{CAMEL}}$ ) as follows:

Regarding each indicator of CAMEL, the null hypothesis $\mathrm{H}_{0}$ could be shown as:

$$
\left.\beta_{n}=0 \text { (where } n=1,2,3 \text { to } 10\right)
$$

The alternative hypothesis $\mathrm{H}_{\mathrm{a}}$ could be shown as:

$$
\begin{gathered}
I_{C A M E L}=\alpha+\beta_{1} S I Z+\beta_{2} S E A 1+\beta_{3} S E A 2+\beta_{5} S E A 3+\beta_{5} S E A 4 \\
+\beta_{6} A T R 1+\beta_{7} A T R 2+\beta_{8} A T R 3+\beta_{9} A T R 4+\beta_{10} A T R 5 \\
\beta_{n} \neq 0(\text { where } n=1,2,3 \text { to 10 })
\end{gathered}
$$

\section{Results of Empirical Study}

Required data include bank size, seasonality, attitude to risk and CAMEL indicators, for a sample of 10 banks, and cover the period from the first quarter 2003 to the fourth quarter 2011. The following table illustrates descriptive statistics of these data: 
Table 4. Descriptive statistics of CAMEL indicators

\begin{tabular}{ccccc}
\hline Variables & Minimum & Maximum & Mean & Std. Deviation \\
\hline C1 & 0.01516 & 0.49428 & 0.07777 & 0.05396 \\
C2 & 0.00520 & 0.44253 & 0.09366 & 0.06145 \\
A1 & 0.00950 & 1.89773 & 0.52715 & 0.10002 \\
A2 & 0.00012 & 0.17076 & 0.00766 & 0.01282 \\
M & 0.06717 & 0.98871 & 0.88300 & 0.07281 \\
E1 & -0.08179 & 0.03560 & 0.00641 & 0.01266 \\
E2 & -1.40398 & 0.42044 & 0.03605 & 0.21825 \\
L1 & 0.00209 & 0.22338 & 0.07049 & 0.03188 \\
L2 & 0.01344 & 1.83033 & 0.13961 & 0.12881 \\
\hline
\end{tabular}

Source: collected and processed by the researcher.

Table 4 shows variable characteristics as a whole that don't indicate these characteristics according to "bank size", "seasonality" or "attitude to risk". The following table illustrates the means of CAMEL indicators, for small-sized banks (SIZ1), big-sized banks (SIZ2), first quarter (SEA1), second quarter (SEA2), third quarter (SEA3) and fourth quarter (SEA4). In addition, it shows CAMEL indicators, for conservative banks (ATR1), moderately conservative banks (ATR2), moderate banks (ATR3), moderately aggressive banks (ATR4) and aggressive banks (ATR5), as follows:

Table 5. Means of CAMEL indicators according to size, seasonality and attitude to risk

\begin{tabular}{cccccccccccc}
\hline Variable & SIZ1 & SIZ2 & SEA1 & SEA2 & SEA3 & SEA4 & ATR1 & ATR2 & ATR3 & ATR4 & ATR5 \\
\hline C1 & 0.0707 & 0.0846 & 0.0768 & 0.0790 & 0.0993 & 0.0660 & 0.0208 & 0.0492 & 0.0726 & 0.0965 & 0.1483 \\
C2 & 0.0867 & 0.0986 & 0.0954 & 0.0939 & 0.1096 & 0.0624 & 0.0310 & 0.0532 & 0.0868 & 0.1177 & 0.1885 \\
A1 & 0.2109 & 0.3605 & 0.3213 & 0.3355 & 0.0635 & 0.0940 & 0.9551 & 0.1427 & 0.2165 & 0.2868 & 0.2396 \\
A2 & 0.0040 & 0.0065 & 0.0076 & 0.0127 & 0.0086 & 0.0033 & 0.0018 & 0.0069 & 0.0078 & 0.0088 & 0.0102 \\
M & 0.8820 & 0.8837 & 0.8869 & 0.8795 & 0.0049 & 0.0138 & 0.8750 & 0.8858 & 0.8834 & 0.8917 & 0.8766 \\
E1 & 0.0040 & 0.0065 & 0.0078 & 0.0073 & 0.0138 & 0.1452 & 0.0031 & 0.0067 & 0.0105 & 0.0063 & 0.0005 \\
E2 & 0.0302 & 0.0477 & 0.0403 & 0.0261 & 0.0825 & 0.0546 & 0.0290 & 0.0644 & 0.0928 & 0.0369 & -0.1022 \\
L1 & 0.0700 & 0.0728 & 0.0735 & 0.0657 & 0.1372 & 0.1512 & 0.0568 & 0.0761 & 0.0696 & 0.0554 & 0.0705 \\
L2 & 0.1554 & 0.1346 & 0.1303 & 0.1382 & 0.0635 & 0.0940 & 0.1397 & 0.1292 & 0.1430 & 0.1317 & 0.1562 \\
\hline
\end{tabular}

Source: collected and processed by the researcher.

Table 5 shows different means of CAMEL indicators for different categories of size, seasonality and attitude to risk. However, these differences don't indicate significance. This paper aims at testing the significance of these differences.

To test the research hypotheses, ANOVA is conducted to check the significance of differences between CAMEL indicators, according to size, seasonality and attitude to risk. The following table illustrates the results of this test as follows: 
Table 6. Testing Hypotheses using ANOVA

\begin{tabular}{|c|c|c|c|}
\hline Indicator & Size & Seasonality & Attitude towards risk \\
\hline \multirow[t]{2}{*}{$\mathrm{C} 1$} & 13.99 & 1.013 & 95.995 \\
\hline & $(0.000)^{* * *}$ & $(0.387)$ & $(0.000)^{* * *}$ \\
\hline \multirow[t]{2}{*}{$\mathrm{C} 2$} & 15.44 & 0.605 & 217.683 \\
\hline & $(0.000)^{* * *}$ & $(0.612)$ & $(0.000)^{* * *}$ \\
\hline \multirow[t]{2}{*}{ A1 } & 0.204 & 1.000 & 0.424 \\
\hline & $(0.652)$ & $(0.393)$ & $(0.791)$ \\
\hline \multirow[t]{2}{*}{ A2 } & 8.769 & 7.739 & 1.921 \\
\hline & $(0.003)^{* * *}$ & $(0.000)^{* * *}$ & $(0.106)$ \\
\hline \multirow[t]{2}{*}{$\mathbf{M}$} & 1.007 & 0.163 & 0.329 \\
\hline & $(0.316)$ & $(0.912)$ & $(0.858)$ \\
\hline \multirow[t]{2}{*}{ E1 } & 26.84 & 1.580 & 7.760 \\
\hline & $(0.000)^{* * *}$ & $(0.194)$ & $(0.000)^{* * *}$ \\
\hline \multirow[t]{2}{*}{$\mathbf{E 2}$} & 19.296 & 0.180 & 10.709 \\
\hline & $(0.000)^{* * *}$ & $(0.910)$ & $(0.000)^{* * *}$ \\
\hline \multirow[t]{2}{*}{ L1 } & 3.716 & 1.116 & 3.390 \\
\hline & $(0.055)^{*}$ & $(0.343)$ & $(0.010)^{*}$ \\
\hline \multirow[t]{2}{*}{$\mathbf{L 2}$} & 0.596 & 0.655 & 0.554 \\
\hline & $(0.441)$ & $(0.580)$ & $(0.696)$ \\
\hline
\end{tabular}

Each cell contains the $\mathrm{F}$ value, with the significance level between brackets, where * denotes p-value of $10 \%, * *$ denotes $5 \%$ and $* * *$ denotes $1 \%$.

Testing Hypotheses using ANOVA show, at p-value of 0.05 , that there's a significant differences between CAMEL indicators, according to bank size, as follows:

For capital adequacy (C): Tests indicate that capital adequacy indicators of small banks are significantly different from those of big ones. Also, they are significantly different according to banks' attitude to risk, while seasonality effect is not significant. This has been conducted using Net Worth to Risky Assets (C1) and Net Worth to Deposits (C2).

For asset quality (A): Tests show that Provisions to Assets (A2) of small banks are significantly different from those of big ones. Also, it's significantly different according to seasonality, while banks' attitude to risk effect is not significant. Tests don't indicate any effects on Loan Provisions to Loans (A1).

For management (M): Tests don't indicate any significant differences in Risky Assets to Assets (M) according to size, seasonality, or attitude to risk.

For earnings (E): Tests show that earnings indicators of small banks are significantly different from those of big ones. Also, they are significantly different according to banks' attitude to risk, while seasonality effect is not significant. This has been conducted using Return on Equity (E1) and Return on Assets (E2).

For liquidity (L): Tests don't indicate any significant differences in each of Legal Reserve Ratio (L1) and Legal Liquidity Ratio (L2) according to size, seasonality, or attitude to risk at p-value of 0.05 . Also, they show significant differences in L2 due to size and attitude to risk at p-value of 0.10 .

Based on the previous analysis, the null hypothesis is rejected. This means that the alternative one could be accepted showing significant difference in Egyptian banks' performance, due to:

Size: where tests indicate significant differences in capital adequacy (C), asset quality (A) and earnings (E), while management $(\mathrm{M})$ and liquidity $(\mathrm{L})$ indicators do not address such differences. So, regarding size effect, alternative hypothesis could be accepted. 
Seasonality: where empirical evidence indicates significant differences in asset quality (A), while capital adequacy (C), earnings (E), management (M) and liquidity (L) indicators do not address such differences. So, regarding seasonality effect, alternative hypothesis could be accepted.

Attitude to risk: where tests address significant differences in capital adequacy (C) and earnings (E), while asset quality (A), management (M) and liquidity (L) indicators do not indicate such differences. So, regarding attitude to risk effect, alternative hypothesis could be accepted.

To check the previous results, robustness check has been conducted using step-wise regression analysis and provides the following results:

Table 7. Determinants of CAMEL indicators

\begin{tabular}{|c|c|c|c|c|c|c|c|c|}
\hline Indicator & Constant & Size & $S E A 1$ & $S E A 2$ & $S E A 3$ & SEA4 & ATR & $R^{2}$ \\
\hline \multirow[t]{2}{*}{$\mathrm{C} 1$} & -0.013 & $\mathbf{- 0 . 0 1 2}$ & - & - & - & - & 0.031 & 0.611 \\
\hline & $(-2.407)^{* *}$ & $(-2.188)^{* *}$ & & & & & $(18.705)^{* * *}$ & \\
\hline \multirow[t]{2}{*}{$\mathrm{C} 2$} & -0.028 & -0.012 & - & - & - & - & 0.042 & 0.793 \\
\hline & $(-5.635)^{* * *}$ & $(-2.429)^{* *}$ & & & & & $(27.515)^{* * *}$ & \\
\hline $\mathrm{A} 1$ & - & - & - & - & - & - & - & - \\
\hline \multirow[t]{2}{*}{ A2 } & 0.007 & -0.005 & - & 0.003 & - & -0.007 & - & 0.592 \\
\hline & $(8.545)^{* * *}$ & $(-3.096)^{* * *}$ & & $(2.247)^{* *}$ & & $(4.465)^{* * *}$ & & \\
\hline M & - & - & - & - & - & - & - & - \\
\hline \multirow[t]{2}{*}{ E1 } & 0.009 & 0.008 & - & - & - & - & -0.001 & 0.485 \\
\hline & $(4.961)^{* * *}$ & $(4.819)^{* * *}$ & & & & & $(-2.079)^{* *}$ & \\
\hline \multirow[t]{2}{*}{ E2 } & 0.134 & 0.111 & - & - & - & - & -0.039 & 0.370 \\
\hline & $(4.3490 * * *$ & $(3.758)^{* * *}$ & & & & & $(-4.239)^{* * *}$ & \\
\hline L1 & - & - & - & - & - & - & - & - \\
\hline L2 & - & - & - & - & - & - & - & - \\
\hline
\end{tabular}

Each cell contains the estimated parameters, with std error between brackets, where $*$ denotes $\mathrm{p}$-value of $10 \%, * *$ denotes $5 \%$ and $* * *$ denotes $1 \%$.

\section{Summary and Concluded Remarks}

This paper aims at analyzing the effects of size, seasonality and attitude to risk, on the performance Egyptian banks, using a sample of 10 banks during the period from 2003 to 2011. Results indicate the significance of differences between CAMEL indicators, according to size, seasonality and attitude to risk. Robustness check assures the significance of these effects, where indicators of capital adequacy and earnings are affected by both of size and attitude to risk, while asset quality is affected by size and seasonality.

Table (6) indicates testing hypotheses (regarding significance of differences) without showing the type of these differences while table (5) illustrates what CAMEL indicators may tell. Table (8) shows testing hypotheses and type of significant differences, as follows:

Table 8. Testing hypotheses and type of significant differences

\begin{tabular}{cccccc}
\hline Item & Category & $\boldsymbol{C}$ & $\boldsymbol{A}$ & $\boldsymbol{M}$ & $\boldsymbol{E}$ \\
\hline Size & Small & Worse & Worse & & Worse \\
& Big & Best & Best & & Best \\
Seasonality & 1st Quarter & & Moderate & & \\
& 2nd. Quarter & & Best & & \\
\hline
\end{tabular}




\begin{tabular}{|c|c|c|c|c|}
\hline & 3rd. Quarter & & Moderate & \\
\hline & 4th. Quarter & & Worse & \\
\hline Attitude toward & Conservative & Worse & & Worse \\
\hline \multirow[t]{4}{*}{ risk } & Moderately conservative & Bad & & Moderate \\
\hline & Moderate & Moderate & & Best \\
\hline & Moderately aggressive & Good & & Moderate \\
\hline & Aggressive & Best & & Worse \\
\hline
\end{tabular}

Results reveal that CAMEL indicators have different sensitivities to size, seasonality and attitude to risk. These may be explained, as follows:

Big banks have better performance (according to capital adequacy, asset quality and earning) than small. This may shed a light on the necessity of enhancing performance through developing facilities that provide a strong competitive situation. Small banks can't provide such facilities that depend on banks' image, system and human capital.

Seasonality affects asset quality by a surprising way, as it tends to be good at the end of the second quarter, becomes moderate at the end of the third one, continues to be bad at the fourth quarter and turn to be moderate (another time) at the end of the first one. This indicates that asset quality is dressed at the end of fiscal year for providing an informational content that doesn't express the real situation.

Attitude to risk affects capital adequacy in accordance with Basel agreement, as it tends to be at its lowest level in the conservative case, becomes a little bit high in moderately conservative case, continues to be higher in moderately aggressive and aggressive cases. Also, it reaches its highest level in the very aggressive case.

Attitude to risk affects earnings regardless the traditional risk-return relationship, as it tends to be at its lowest level in the conservative and aggressive cases, and becomes at its highest level in the in moderate case. This may need a special effort to be elaborated as applied on longer periods and different markets.

\section{References}

Acharya, V., Gale, D., \& Yorulmazer, T. (2009). Rollover Risk and Market Freezes. Working paper, New York University.

Al-Farisi, A., \& Hendrawan, R. (2012). Effect of Capital Structure on Banks Performance: A Profit Efficiency Approach Islamic and Conventional Banks Case in Indonesia. International Research Journal of Finance and Economics, 86, 6-19.

Altman, I. (1968). Financial Ratios, Discriminate Analysis and Prediction of Corporate Bankruptcy. Journal of Finance, 23(4), 589-609. http://dx.doi.org/10.1111/j.1540-6261.1968.tb00843.x

Anis, O., \& Sami, R. (2012). Financial liberalization (FL), Environment Variables and Cost Efficiency of Tunisian Banking System. Journal of Applied Finance and Banking, 2(5), 1-25.

Barth, J., Caprio, G., \& Levine, R. (2008). Bank Regulations Are Changing: For Better or Worse? World Bank Policy Research, Working Paper No 4646.

Beaver, W. (1966). Financial Ratios as Predictors of Failure. Journal of Accounting Research, 4, 71-111. Retrieved from http://www.jstor.org/stable/2490171

Ben Naceur, S., \& Omran, M. (2011). The Effects of Bank Regulations, Competition, and Financial Reforms on Banks' Performance. Emerging Markets Review, 12, 1-20. http://dx.doi.org/10.1016/j.ememar.2010.08.002

Berger, A., \& Bouwman, C. (2012). How Does Capital Affect Bank Performance During Financial Crises? Unpublished Manuscript, University of South Carolina.

Berger, A., Bouwman, C., Kick, T., \& Schaeck, K. (2011). Bank Risk Taking and Liquidity Creation following Regulatory Interventions and Capital Support. Deutsche Bundesbank Discussion Paper, Series 2, No $05 / 2010$.

Berger, A., DeYoung, R., Flannery, M., Lee, D., \& Öztekin, Ö. (2008). How Do Large Banking Organizations Manage Their Capital Ratios? Journal of Financial Services Research, 34, 123-149. http://dx.doi.org/10.1007/s10693-008-0044-5 
Black, L., \& Hazelwood, L. (2012). The Effect of TARP on Bank Risk-Taking. International Finance Discussion, IFDP 1043, Board of Governors of the Federal Reserve System.

Carvallo, O., \& Kasman, A. (2005). Cost Efficiency in the Latin American and Caribbean Banking Systems. Journal of International Financial Markets Institution and Money, 15, 55-72. http://dx.doi.org/10.1016/j.intfin.2004.02.002

Central Bank of Egypt. (2011). Annual Report.

Central Bank of Egypt. (2011). Economic Review.

Cole, R., \& Gunther, J. (1995). A CAMEL Rating's Shelf Life. Retrieved from http://ssrn.com/abstract=1293504

Curry, T., Fissel, G., \& Ramirez, C. (2006). The Effect of Bank Supervision on Loan Growth. FDIC Center for Financial Research, Working Paper No. 2006-12.

Demirgüç-Kunt, A., \& Detragiache, A. (2011). Basel Core Principles and Bank Soundness Does Compliance Matter? Journal of Financial Stability, 7(4), 179-190. http://dx.doi.org/10.1016/j.jfs.2010.03.003

Diamond, D., \& Rajan, R. (2009). Fear of Fire Sales and the Credit Freeze. A working paper, University of Chicago.

Gayed, N., Gayed, P., \& Alber, N. (2009). Using the Marketing Approach to Evaluate Banking Performance: The Case of Egypt. Retrieved from http://ssrn.com/abstract=1519087

Gilbert, R., Meyer, A., \& Vaughan, M. (2002). Could a CAMELS Downgrade Model Improve Off-Site Surveillance? Federal Reserve Bank of St. Louis Review, 84(1), 47-63.

Guidara, A., Lai, V., \& Soumaré, I. (2011). Banks' Capital Buffer, Risk and Performance in Different Business and Regulation Cycles: Evidence from Canadian Sector. The 44th Annual Conference of the Canadian Economic Association, Quebec City.

Gunter, J., \& Moore, R. (2003). Early Warning Models in Real Time. Journal of Banking and Finance, 27(10), 1979-2001. http://dx.doi.org/10.1016/S0378-4266(02)00314-X

Hassan, K., \& Sanchez, B. (2007). Efficiency Determinants and Dynamic Efficiency Changes in Latin American Banking Industries. Networks Financial Institute Working Paper, 2007-WP-32. Retrieved from http://ssrn.com/abstract=1087045

ING North America Insurance Corporation. (2010). Model Portfolios A model that lives up to your personal $\begin{array}{lllll}\text { standards. } & I N G & \text { Special } & \text { Report. } & \text { Retrieved }\end{array}$ http://www6.ingretirementplans.com/SponsorExtranet/ModelPortfolios.pdf

Kanas, A. (2013). Bank Dividends, Risk, and Regulatory Regimes. Journal of Banking and Finance, 37, 1-10. http://dx.doi.org/10.1016/j.jbankfin.2012.05.018

King, T., Nuxoll, D., \& Yeager, T. (2006). Are the Causes of Bank Distress Changing? Can Researchers Keep Up? Federal Reserve Bank of St. Louis Review, 88(1), 57-80.

Maishanu, M. (2004). A Univariate Approach to Predicting Failure in the Commercial Banking Sub-Sector in Nigerian. Journal of Accounting Research, 1(1).

Njoku, J. (2012). Surveillance Model of Going Concern in Banking. African Journal of Accounting, Auditing and Finance, 1(1).

Osborne, M., Fuertes, A., \& Milane, A. (2012). In Good Times and in Bad: Bank Capital Ratios and Lending Rates. Retrieved from http://ssrn.com/abstract=1971324

Paul, S., \& Kaestner, L. (2007). Privatization and Banking Performance. Retrieved from $\mathrm{http}: / / \mathrm{ssrn} . \mathrm{com} / \mathrm{abstract}=995185$

Petrella, G., \& Resti, A. (2012). Supervisors as Information Producers: Do Stress Tests Reduce Bank Opaqueness? Retrieved from http://ssrn.com/abstract=1968681

Sahut, J., \& Mili, M. (2009). Determinants of Banking Distress and Merger as Strategic Policy to Resolve Distress. Retrieved from http://ssrn.com/abstract=1343814

Saunders, A. (1994). Financial Institutions Management: A Modern Perspective. Ill.: Irwin \& Inc.

Schaeck, K., \& Čihák, M. (2007). Banking Competition and Capital Ratios. Retrieved from http://ssrn.com/abstract $=1016246$ 
Tatom, J., \& Houston, R. (2011). Predicting Failure in the Commercial Banking Industry. Retrieved from http://mpra.ub.uni-muenchen.de/34608/

Vazquez, F., \& Federico, P. (2012). Bank Funding Structures and Risk: Evidence from the Global Financial Crisis. International Monetary Fund, WP/12/29

Wirnkar, A., \& Tanko, M. (2008). CAMELs and Banks' Performance Evaluation: The Way Forward. Retrieved from http://ssrn.com/abstract $=1150968$

\section{Notes}

Note 1. Small banks are those banks that have less than average size in terms of deposits, while big banks have average or more than average size in terms of deposits.

Note 2. According to ING North America Insurance Corporation (2010), attitude to risk may be checked by the selected class of portfolios, where they are categorized into five classes: aggressive, moderately aggressive, moderate, moderately conservative and conservative.

\section{Copyrights}

Copyright for this article is retained by the author(s), with first publication rights granted to the journal.

This is an open-access article distributed under the terms and conditions of the Creative Commons Attribution license (http://creativecommons.org/licenses/by/3.0/). 